\title{
Editorial
}

Miriam De Cock*

\section{Editor's Introduction to the Topical Issue "Reception of the Biblical and Patristic Heritage: Case Studies and Reflections on Theory and Method"}

https://doi.org/10.1515/opth-2020-0186

received October 30,2021

In the past decades, the Bible's reception, which tends to include both its interpretation and its use, has drawn considerable scholarly attention, particularly, though not exclusively, in the English-speaking world. Indeed, most major presses in the fields of theology and religious studies now have at least one series or substantial handbook dedicated to the reception of the Bible, such as The Oxford Handbook of the Reception History of the Bible, The New Cambridge History of the Bible volumes, Bloomsbury's Biblical Reception series, or the Blackwell Bible Commentary Series' significant focus on reception. ${ }^{1}$ De Gruyter has itself been one of the field's leading publishers, issuing such monograph series as Studies of the Bible and its Reception or Handbooks of the Bible and Its Reception, the closely-related Encyclopedia of the Bible and its Reception, and the journal Journal of the Bible and its Reception. All four attend to the various ways in which the books of the Bible have been used and interpreted in text, music, art, and other media throughout the centuries and in various cultural contexts. The scholarly shift toward the Bible's reception, rather than its historicity, is now so widespread and thoroughgoing, that an exhaustive account of the bibliography dedicated to the subject is nearly impossible. On the other hand, in the field of patristics or Christianity in Late Antiquity, as some would have it, one ancient author's reception of another has been and continues to be a methodological mainstay; scholars continue to seek to determine a given author's literary sources in good "history of ideas" fashion. Scholars of both fields - to the extent that they can be considered to belong to two distinct fields - would do well to glean from each other's results and reception historical observations. ${ }^{2}$

In this special issue, we have sought to place examples of Christian reception of the biblical text alongside examples of the reception of patristic authors and texts, from Christianity's earliest centuries to the modern period. It is this combination in which the issue's uniqueness is found. In fact, eight of the eleven essays of the issue focus on the reception of patristic authors to one extent or another. This inclusion of case studies of the reception of patristic authors alongside the reception of biblical texts is a way of acknowledging that in many cases patristic authors became a source of authority in their own right in a way that either paralleled or, in some cases, competed with that of the biblical text.

1 Lieb et al., The Oxford Handbook of the Reception History of the Bible; The New Cambridge History; Clines and Exum, Biblical Reception; and Sawjer, Blackwell Bible Commentary Series.

2 This is to say nothing of the contributions of the adjacent field of Classics, in which reception historical work is anything but new.

\footnotetext{
* Corresponding author: Miriam De Cock, Department of Theology, Aarhus University, Aarhus, Denmark, e-mail: mirde@cas.au.dk
} 
Indeed, the essay of Valeria Dessy, "The Authority of the Bible and the Church Fathers in Adolf von Harnack's Thought," demonstrates that for Harnack both biblical and patristic writings were equally authoritative and, significantly, that his historical-theological treatment of them led him to deem the patristic writings as the necessary follow up to what he understood as the New Testament's obscurities. My own contribution, "Theodoret of Cyrus and his Exegetical Predecessors: A Study of his Biblical Commentary Prefaces," demonstrates that for the fifth-century interpreter, the authority of the exegesis of his early Christian predecessors was of no little importance as he set to the task of interpreting scripture; for him, the exemplary exegete had to have intimate knowledge of and mastery over both scripture and the subsequent Christian tradition. Similarly, Christian Thrue Djurslev's paper, "Hrabanus Maurus' PostPatristic Renovation of 1 Maccabees 1:1-8," highlights how the ninth-century historiographer, Hrabanus Maurus, succeeded in updating the meaning of the authoritative Maccabean text, which contains an account of Alexander the Great's career, for his own medieval context via the use of the Latin patristic tradition's exegesis of it. That is, this Carolingian author found the patristic exegetical tradition to be so authoritative that he used the Latin exegetical glosses to essentially re-write the biblical text itself within his historiographical account of Alexander the Great.

This combination of the reception of the biblical and patristic heritage is also a nod toward the rising scholarly conviction that a rigid distinction between the "New Testament period" and the period that saw the production of subsequent early Christian literature is often historically unhelpful. ${ }^{3}$ The distinction can obscure important continuities between these writings, at the very least from the perspective of the ancient Christian authors themselves. Carl Vennerstrom's essay, “To Those Who Have Ears to Hear': Clement of Alexandria on the Parables of Jesus," for example, highlights that Clement understood himself to have a place within the line of parabolic teaching from Jesus to his disciples and beyond. In fact, Vennerstrom draws on New Testament scholarship to elucidate Clement's parable exegesis, using recent insights of New Testament scholars to draw out previously unnoticed aspects of Clement's exegesis of parables. He highlights the extent to which Clement considers parables to be prophetic and to communicate the redemptive suffering of Jesus, his twelve disciples, and all those who would follow him.

Furthermore, the essays in this special issue arise from the shared conviction amongst its contributors that scholarly theorizing about reception history is best drawn from concrete, specific examples of reception. Accordingly, throughout this issue, the reader will occasionally find the authors pausing to reflect on the implications of their particular case studies for our collective understanding of how reception works and on the problems and challenges one faces in conducting "reception historical" projects.

For example, the other two essays of the issue which are focused on early Christian reception of the biblical text remind us how very selective the act of reception was as these authors made use of the Bible in their own contexts. Martina Vercesi's contribution, "Intimations of Revelation 19-21 in the Early North African Christian Communities," demonstrates that it was these three chapters of the book of Revelation in particular - which include the eschatological war, the millennial kingdom, and the descent of the New Jerusalem - that proved so useful for the North African communities as they sought to articulate an understanding of the end of days in the face of their own tumultuous reality. The other essay focused on biblical reception in particular, Anna-Liisa Rafael's contribution, "Origen and the Story of the Mother and Her Seven Sons: Reimagining Third-Century Caesarean Horizons," also highlights how early Christian authors made much of certain texts or passages within a given book, while disregarding others. Rafael observes that, as he treated 2 Maccabees in his Exhortation to Martyrdom, Origen worked in different ways with the two exemplary figures, the mother of the seven sons and the sage, Eleazar. While Origen presents the speeches of Eleazar almost verbatim for his reader, he is highly selective and paraphrastic concerning the words and actions of the mother. This Rafael explains as the result of the manner in which Origen relates to both figures: while he puts himself in the same chain of tradition as Eleazar (and indeed wise Solomon himself), he distances himself from the mother of the seven, not quoting her words, but describing God's action in the story of her and her sons.

3 For example, this is one of the premises of the recent book on early Christian exegesis by Mitchell, Paul, the Corinthians. 
Christian authors were no less selective as they dealt with the writings of the patristic heritage in their production of new texts. The Christian reception of Origen of Alexandria demonstrates this well, and two essays in this issue are concerned with this very topic. The first, Sara Contini's "'You are Gods' (Ps 81:6): Jerome and the Legacy of Origen's Anthropology," demonstrates that, in his exegesis of the Psalms, Jerome was most certainly aware of Origen's Psalms exegesis, given how closely he follows Origen's own exegetical arguments concerning the dignitas of humanity. Despite this dependence on Origen's exegetical treatment of Ps 81, however, Jerome is careful to articulate his distance from Origen elsewhere, so as to prove himself orthodox with respect to the accepted Trinitarian theology of the day; human beings could simply not be said to share the same substance as the heavenly powers or the members of the Trinity. The second essay focused on the reception of Origen's legacy, "Conflict and Authority: William of Saint-Thierry and Peter Abelard as Readers of Origen," by Carmen Angela Cvetkovic, highlights the different ways that Origen could be used in the Latin tradition of the twelfth century. Contrary to recent scholarship on Origenian reception in this period, Cvetkovic demonstrates that not only was Origen useful for the contemplative tradition of the cloisters, as typified by William of St. Thierry, but also for the scholastic tradition exemplified by Abelard. While the former made use of Origen's exegetical treatment of the biblical text and his thinking on general theological themes by way of paraphrase, the latter tended to quote the third-century thinker explicitly and much more accurately (not to mention more frequently). Following Jerome, however, he was highly critical of Origen concerning matters of doctrine and tended to work mostly with Origen's biblical exegesis.

Not only were Christian authors selective with their use of biblical and patristic sources - both concerning which sources and which sections of a given text they used-but their reflection on the texts or figures of the prior tradition with which they engaged were also ambiguous. That is, their reception or use of a given text or author did not necessarily entail approval or alignment. Three essays in the issue highlight this specifically. The first is the contribution of Taylor Ross, "Cultivation as Immanent Critique: Horticultural Metaphors in Gregory of Nyssa's Reception of Origen and Basil," in which he examines Gregory's De hominis opificio and Apologia in Hexaemeron. Ross argues that Gregory's use of horticultural metaphors, in which his own treatise is a branch on the tree of Basil's homilies, illustrates not only his own work's alignment with and natural development of that of his brother, but also its perfection of it. That is, upon closer scrutiny, Ross demonstrates, Gregory's use of this metaphor allows him to distinguish himself from his brother as the one who understood scripture's бколó "Reception through Polemics: The Internalization of Theological Otherness in Jerome's Heresiology," Katarina Pålsson demonstrates that, despite Jerome's polemics against Jovinian, he nonetheless takes on a significant part of his opponent's thought concerning the themes of marriage and human nature, given the dialogical nature of the heresiological context. Pålsson thus highlights that reception does not necessarily entail acceptance or reuse, but can also include refutation of the other, which in turn gives occasion to reformulate and accordingly shapes one's own views. A third example demonstrates the often ambiguous nature of the act of reception. Maria Fallica's essay, “An Anglo-Syrian Monk: John Wesley's Reception of Pseudo-Macarius," takes us out of the context of Late Antiquity and into the modern period. The ambiguous nature of John Wesley's reception of Pseudo-Macarius is illustrated clearly through an examination of the scholarship on the subject; scholars can simply not agree on the weight or meaning that ought to be assigned to the great Methodist's use of the fourth-century author. Fallica demonstrates that even finding the appropriate language to describe Wesley's use of Pseudo-Macarius highlights the problem; scholars have described it variously as his "Eastern connection," Macarius' "influence” on Wesley, and Wesley's "appropriation" of Macarius' thought, depending on how "Eastern" or "Western" one wants Wesley to be. In this case study, we are confronted with the reality of the limitations and biases of our own position as we approach our historical work.

Finally, some of the contributors were particularly intentional in their use of reception historical theories, which they have taken from disciplines other than the study of religion and theology. This highlights the truly interdisciplinary nature of reception historical work. The insights and methods gleaned from these theories most certainly require further attention and use in the fields of theology and religious studies. For example, in Djurslev's contribution on Hrabanus Maurus, he draws insights from "transformation theory," which provides him with helpful language to describe the nature of the changes or updates 
Hrabanus Maurus introduces into the Maccabean Alexander tradition, given the later cultural context in which he finds himself. Transformation theory urges the historian to move beyond mere reception, working with two spheres, namely, reference, or the context in which one finds the object to be reworked, and reception, the sphere in which the reconstruction of the reference object takes place. Both spheres are modified in this model, for the reception sphere is also impacted by the reference culture.

Another example is Anna-Liisa Rafael's essay on Origen's treatment of the Maccabean martyrs, in which she makes use of ethnographer and scholar of Rabbinic and folklore literature Galit HasanRokem's notions of vertical and horizontal axes of transmission. In Origen's case, the vertical axis (of "intergenerational transmission") is his link to Eusebius of Caesarea, ${ }^{4}$ through whose text, Ecclesiastical History, we in fact encounter the third-century thinker. ${ }^{5}$ The horizontal axis (of "intergroup transmission") is that axis on which we expand the scholarly horizons, for it entails the ancient scholar's (i.e., Origen's) encounter with the realm of discourse beyond "the academy," including women, children, other religious or cultural traditions, and even supernatural creatures. Incorporating the possibility of these voices into her analysis of Origen's reception of the Maccabean martyrs allows Rafael to consider the possibility that Origen's distinctive treatments of the mother of the seven and Eleazar, referred to above, is a kind of response to a popular narrative tradition concerning the mother and her sons, thus moving us beyond a traditional textual reception of an authoritative text.

Katarina Pålsson, in her essay on Jerome's polemics against Jovinian, makes use of the theory of dialogue proposed by the well-known Russian philosopher Mikhail Bakhtin in order to make her argument concerning the dialogical nature of polemics. Two particular aspects of a Bakhtinian approach to dialogue aid Pålsson in her analysis of Jerome's Against Jovinian: (1) there is no pure monologue, thus all utterances are directed toward an answer, the anticipation of which necessarily influences the utterance and implies dialogue; (2) dialogue is not necessarily benevolent, and it is characterized by "unfinalization" or openendedness rather than closure. These concepts result in Pålsson's argument that Jerome's heresiological polemic against Jovinian is performative, that is, it engages with the imagined or anticipated response of the theological other, being simultaneously and inevitably shaped by it in the process.

Lastly, as a way forward in the aforementioned problem of Wesley's reception of Pseudo-Macarius in recent scholarship, Marie Fallica makes use of French Jesuit intellectual Michel de Certeau's discussion of reception. Certeau insists that reading entails appropriation and furthermore that the author as an agent in control of her text does exist, which leads him to conclude that the appropriate question to ask in the work of reception, particularly when religious literature is in focus, is: what is the "spiritual reciprocity" established between the reader and her text? Accordingly, rather than asking what of Pseudo-Macarius remains in the Wesleyan portrait of the Syrian, or whether or not Wesley understood his ancient conversation partner, Fallica (through Certeau) suggests that we ask: who was Wesley's Pseudo-Macarius?

In addition to their interdisciplinarity, each of these four contributors and the theories of which they make use point us beyond "mere" reception, understood as a later text's interpretation or use of an earlier text, tradition, or figure. ${ }^{6}$ Instead, they suggest that we ask additional questions about the transformation of the receiving text or figure, as well as the context to which it is addressed. Such methodological considerations and decisions are undoubtedly one important direction for the future of reception studies, as is further and more thoroughgoing collaboration between those studying the classics, biblical texts, and patristic writings.

Acknowledgements: I wish to thank Stephan Borgehammar, Matthew R. Crawford, Andrew Faulkner, and Mark Elliot for engaging with earlier versions of the contributions to this topical issue.

\footnotetext{
4 We need not stop with one vertical axis, however. As Rafael herself makes clear, Origen receives the text of the Maccabean martyrs in his library in Caesarea at an earlier point on the vertical axis.

5 Of course, we also encounter Origen in his own writings, but the influence of Eusebius' account of Origen's life is uncontrovertibly influential on the influential third-century author's reception.

6 Such traditional reception work is often accompanied by the scholar's assessment of the extent to which the later figure really understood the earlier or "reference" text.
} 
Funding information: Thanks to the generous financial support of the Carlsberg Foundation (grant number CF19-0832) contributors to this special issue can offer their work in Open Access format.

Conflict of interest: Author states no conflict of interest.

\section{References}

Clines, David A. and Exum, J. Cheryl, eds. Biblical Reception, Vol. 1-5. London: Bloomsbury Publishing, 2015-2018. Lieb, Michael, Mason, Emma, Roberts, Jonathan, and Rowland, Christopher, eds. The Oxford Handbook of the Reception History of the Bible. Oxford: Oxford University Press, 2011.

Mitchell, Margaret M. Paul, the Corinthians, and the Birth of Christian Hermeneutics. Cambridge: Cambridge University Press, 2010.

Sawjer, John, ed. Blackwell Bible Commentary Series. Hoboken, NJ: Wiley Blackwell, 2005-2021.

Carleton Paget, James, Schaper, Joachim, Marsden, Richard, Matter, E. Ann, Cameron, Euan, Riches, John, eds. The New Cambridge History of the Bible, Vol. 1-4. Cambridge: Cambridge University Press, 2013-2016. 